\title{
Antifungal Activity of Parmotrema tinctorum (Delise ex Nyl.) Hale and Parmotrema cristiferum (Taylor) Hale Against Seed Mycoflora - A Comparative Study
}

\author{
Prashith Kekuda T.R ${ }^{1}$ and Vinayaka K. $\mathbf{S}^{2^{*}}$ \\ ${ }^{1}$ Department of Microbiology, S.R.N.M.N College of Applied Sciences, N.E.S Campus, Balraj Urs Road, \\ Shivamogga-577201, Karnataka, India
}

${ }^{2}$ Department of Botany, Kumadvathi First Grade College, Shimoga Road, Shikaripura, Karnataka, India

\begin{tabular}{lll}
\hline & \multicolumn{1}{c}{ Abstract } & Article Information \\
\hline Lichens are composite organisms comprising of a photobiont and a mycobiont. Studies have & Article History: \\
shown that extracts and secondary metabolites from lichens exhibit various bioactivities. The & Received $: 26-01-2016$ \\
present study evaluates antifungal potential of crude methanolic extract of two corticolous & Revised $: 10-03-2016$ \\
Parmotrema species viz. Parmotrema tinctorum (Delise ex Nyl.) Hale and Parmotrema & Accepted : 15-03-2016 \\
\cline { 2 - 2 } cristiferum (Taylor) Hale against a panel of fungi isolated from seeds of maize and & Keywords: \\
groundnut. Extraction of powdered lichens was carried out by maceration process using & Lichens \\
methanol. Antifungal activity was evaluated by poisoned food technique. Both extracts were & Parmotrema \\
effective in causing dose dependent inhibition of radial growth of test fungi in poisoned & Antifungal \\
plates. Among lichens, marked inhibitory activity was shown by P. cristiferum. At 1mg/ml & Poisoned food technique \\
concentration, P. cristiferum displayed an inhibition of >50\% of all test fungi. The antifungal & Seed mycoflora \\
\cline { 2 - 2 } activity of two Parmotrema species against seed mycoflora could be ascribed to the & Vinayaka K.S \\
presence of secondary metabolites in extracts. & E-mail: \\
Copyright@2016 STAR Journal, Wollega University. All Rights Reserved. & ks.vinayaka@gmail.com \\
\hline
\end{tabular}

\section{INTRODUCTION}

Fungi cause a number of devastating diseases in crops leading to pre- and post-harvest losses. Fungi cause diseases in field as well as storage conditions. Farmers suffer from considerable economic loss due to fungal diseases which may account for $>50 \%$ in severe disease incidences. Fungi that are associated with the seeds are known to cause seed rot, seed abortion, seedling damage and reduction in nutritive value and germination. Management of phytopathogenic fungi involves the use of synthetic fungicide. However, the use of chemicals is often associated with several drawbacks including resistance development in pathogens. Hence, in recent years much emphasis has been focused on natural products having antifungal activity. Lichens seems to be one of the promising alternatives for management of fungal pathogens (Punja and Utkhede, 2003; Halama and Van Haluvin, 2004; Suberu, 2004; Chang et al., 2008; AlReza et al., 2010; Kowalski et al., 2011; Goel et al., 2011; Al-Aksar, 2012; Chandra \& Mahesh, 2013; Bahraminejad et al., 2013). Lichens are composite organisms that comprise of a photosynthetic partner (a photobiont) and a fungal partner (a mycobiont). Lichens usually occur in one of the three growth forms viz. crustose, foliose and fruticose. Worldwide, lichens are used as food, flavoring agent and to treat several diseases or disorders. Lichens are known to produce secondary metabolites (often referred to as lichen substances) that seldom occur in other organisms. Among the metabolites, depsides and depsidones are most common. Studies have shown that extracts and purified metabolites from lichens exhibit diverse biological activities (Karunaratne et al., 2005; Molnár and Farkas, 2010; Goel et al., 2011; Thadhani et al., 2012; Shrestha and St. Clair, 2013; Babiah et al., 2014). Parmotrema A. Massal. is one of the largest genus of lichens in the family Parmeliaceae comprising about 350 species. The genus name Parmotrema literally means perforate apothecia (Greek parmos - cup; trema perforation). It belongs to the family Parmeliaceae and the species are characterized by large foliose thalli with broad lobes (Divakar and Upreti, 2005; Jayalal et al., 2013; Michlig et al., 2014; Vivek et al., 2014). In the present study, we evaluated antifungal activity of two Parmotrema species viz. $P$. tinctorum and $P$. cristiferum against fungi isolated from seeds of maize and ground nut. 


\section{MATERIALS AND METHODS}

Collection and Identification of Lichens

The corticolous macrolichens of this study viz. $P$. tinctorum (on Areca catechu) and P. cristiferum (on Mangifera indica) were collected at the outskirts of Shikaripura, Shivamogga district, Karnataka, India during January 2014. The intact thalli of lichens were carefully separated from the bark of host trees and were brought to the laboratory in labeled pouches. Identification of lichens was carried out on the basis of morphological, anatomical, color tests ( $\mathrm{K}, \mathrm{C}, \mathrm{KC}$ and $\mathrm{P}$ tests) and secondary metabolites detected by thin layer chromatography (Orange, 2001; Divakar and Upreti, 2005; Awasthi, 2007). Details on results of color tests and the secondary metabolites detected are shown in Table 1.

Table 1: Color test and TLC of lichens

\begin{tabular}{ccc}
\hline Lichen & Color Test & Secondary Metabolites \\
\hline P. tinctorum & Cortex K+ yellow; Medulla K-, C +red, KC +red, P - & Atranorin, Lecanoric acid \\
P. cristiferum & Cortex K+ yellow; Medulla K+ red; C-, P+ orange & Atranorin , Salazinic acid, con-salazinic acid \\
\hline
\end{tabular}

\section{Extraction}

The dried lichen materials were powdered and extracted by maceration process using methanol (HiMedia, Mumbai). A known quantity $(10 \mathrm{~g})$ of each of the lichen powder was left in methanol $(100 \mathrm{ml})$ a stoppered container. The contents were mixed occasionally. After 48 hours, the contents were filtered through 4-fold muslin cloth followed by Whatman filter paper No: 1 . The filtrates were dried at room temperatures to obtain crude extract of lichens (Agbor, 2015)

\section{Test Fungi}

Isolation of seed-borne fungi was carried out by standard blotter method. A total of 9 fungi viz. Helminthosporium sp., Curvularia sp., Alternaria sp., Mucor sp. and Aspergillus fumigatus were isolated from maize seeds. Fungi viz. Aspergillus niger, A. flavus, Penicillium sp. and Rhizopus sp. were isolated from ground nut seeds. Identification of the fungi was made on the basis of cultural and microscopic characteristics. The fungi were maintained on Potato dextrose agar (PDA; HiMedia, Mumbai) slants under refrigeration.

\section{Antifungal Activity of Extract}

The antifungal activity of crude extracts of selected lichens was evaluated by Poisoned food technique. PDA medium, sterilized by autoclaving, poisoned with the lichen extracts $(0.5$ and $1.0 \mathrm{mg} / \mathrm{ml}$ of medium) and poured into sterile petri dishes. The test fungi were allowed to grow in control (without extract) and poisoned PDA plates for a period of 5 days at room temperature. Later, the diameter of fungal colonies was measured in mutual perpendicular directions. Antifungal effect of lichen extracts, in terms of inhibition of radial growth of test fungi, was determined using the formula:

$$
\text { Inhibition of fungal growth }(\%)=(\mathrm{C}-\mathrm{T} / \mathrm{C}) \times 100
$$

Where ' $C$ ' and ' $T$ ' denotes the diameter of fungal colonies in control and poisoned plates respectively (Vivek et al., 2014).

\section{Statistical Analysis}

The experiment was carried out in triplicates $(n=3)$ and the results are presented as Mean \pm S.D (Standard deviation).

\section{RESULTS AND DISCUSSION}

Lichens and their metabolites are shown to be promising sources of antifungal agents against a range of fungi including plant pathogenic fungi (Halama and Van Haluvin, 2004; Goel et al., 2011; Kowalski et al., 2011; Karabulut and Ozturk, 2015). It is shown that Parmotrema species exhibit antifungal activity against wide range of phytopathogenic fungi including seed-borne fungi (Tiwari et al., 2011; Kekuda et al., 2014; Babiah et al., 2014; Vivek et al., 2014; Devi et al., 2015; Shivanna and Garampalli, 2015). In the present study, we evaluated the antifungal potential of extract from $P$. tinctorum and $P$. cristiferum against fungi isolated from seeds of maize and ground nut by poisoned food technique. A reduction in mycelial growth of test fungi in poisoned plates is an indication of antifungal potential. Both lichens were effective in inhibiting the growth of test fungi in a dose dependent manner. Among lichens, $P$. cristiferum was found to inhibit test fungi to higher extent. At $1 \mathrm{mg} / \mathrm{ml}$ concentration of $P$. tinctorum and $P$. cristiferum extract, the extent of inhibition of test fungi was in the range $33.33 \%$ to $74.08 \%$ and $52.94 \%$ to $79.06 \%$ respectively. An inhibition of $>50 \%$ of all test fungi was observed at an extract concentration of $1 \mathrm{mg} / \mathrm{ml}$ of $P$. cristiferum. In case of $P$. tinctorum, only 4 out of 9 test fungi were inhibited to $>50 \%$ at $1 \mathrm{mg} / \mathrm{ml}$ extract concentration. Fungi such as Curvularia sp., Mucor sp. and Rhizopus sp. were inhibited to appreciable extent when compared to other fungi (Table 2; Figure 1).

Few studies have been carried out to investigate antifungal activity of Parmotrema species against seed mycoflora. In an earlier study, Vivek et al. (2014) revealed the inhibitory potential of $P$. tinctorum against Alternaria sp., Helminthosporium sp. and Aspergillus flaus isolated from seeds of sorghum. Kekuda et al. (2015) showed the potential of $P$. cristiferum to inhibit mycelial growth of fungi viz. Alternaria sp., Helminthosporium sp., Fusarium sp. and Curvularia sp. isolated from moldy grains of sorghum. In the present study, thin layer chromatogram revealed the presence of atranorin in both lichens. Compounds viz. lecanoric acid and orsellinic acid were present in $P$. tinctorum while salazinic acid and con-salazinic acid were present in $P$. cristiferum. It is shown from earlier studies that lichen metabolites such as atranorin (Goel et al., 2011), lecanoric acid (Thadhani et al., 2012), salazinic acid (Candan et al., 2007; Goel et al., 2011) exhibit antimicrobial activity. In the present study, the observed antifungal potential of $P$. tinctorum and $P$. cristiferum to inhibit seed-borne fungi could be ascribed to the presence of these metabolites. 
Table 2: Colony diameter of test fungi in control and poisoned plates

\begin{tabular}{|c|c|c|c|c|c|}
\hline \multirow{2}{*}{ Test Fungi } & \multicolumn{5}{|c|}{ Colony Diameter in cm (Mean \pm S.D) } \\
\hline & Control & $P t^{*} 0.5 \mathrm{mg} / \mathrm{ml}$ & $\mathrm{Pt} * 1.0 \mathrm{mg} / \mathrm{ml}$ & $\mathrm{Pc}^{* *} 0.5 \mathrm{mg} / \mathrm{ml}$ & $\mathrm{Pc}^{* *} 1.0 \mathrm{mg} / \mathrm{m}$ \\
\hline Helminthosporium sp. & $5.10 \pm 0.00$ & $3.80 \pm 0.10$ & $3.40 \pm 0.00$ & $3.60 \pm 0.00$ & $2.4 \pm 0.00$ \\
\hline Curvularia sp. & $4.63 \pm 0.05$ & $2.83 \pm 0.05$ & $1.20 \pm 0.00$ & $2.03 \pm 0.05$ & $1.03 \pm 0.05$ \\
\hline Alternaria sp. & $3.90 \pm 0.00$ & $3.30 \pm 0.00$ & $2.13 \pm 0.05$ & $2.20 \pm 0.10$ & $1.60 \pm 0.00$ \\
\hline A. fumigatus & $2.83 \pm 0.05$ & $2.20 \pm 0.00$ & $1.30 \pm 0.00$ & $1.93 \pm 0.05$ & $1.23 \pm 0.05$ \\
\hline Mucor sp. & $6.50 \pm 0.10$ & $3.40 \pm 0.10$ & $2.70 \pm 0.17$ & $3.10 \pm 0.00$ & $2.20 \pm 0.00$ \\
\hline A. niger & $4.40 \pm 0.00$ & $3.10 \pm 0.00$ & $2.40 \pm 0.00$ & $2.40 \pm 0.00$ & $1.80 \pm 0.00$ \\
\hline A. flavus & $3.33 \pm 0.05$ & $2.83 \pm 0.05$ & $2.10 \pm 0.00$ & $2.50 \pm 0.10$ & $1.53 \pm 0.05$ \\
\hline Penicillium sp. & $3.10 \pm 0.10$ & $2.50 \pm 0.10$ & $1.90 \pm 0.00$ & $2.23 \pm 0.05$ & $1.40 \pm 0.10$ \\
\hline Rhizopus sp. & $6.83 \pm 0.05$ & $3.23 \pm 0.05$ & $2.10 \pm 0.10$ & $2.40 \pm 0.00$ & $1.43 \pm 0.05$ \\
\hline
\end{tabular}

$\mathrm{Pt}^{\star}$ - P. tinctorum; $\mathrm{Pc}^{\star \star}-$ P. cristiferum

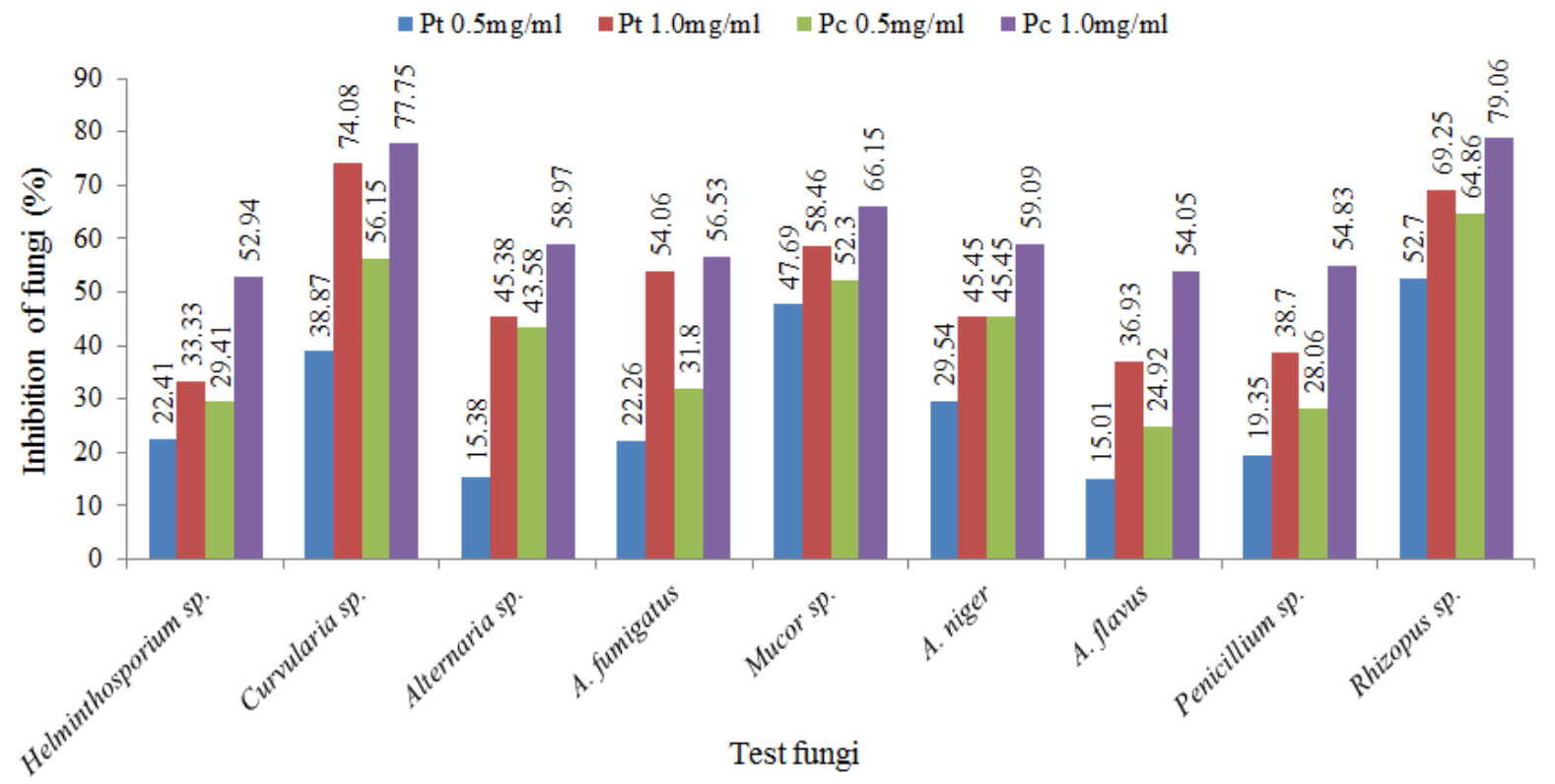

Figure 1: Extent of inhibition of test fungi by extracts of Parmotrema species (Pt- P. tinctorum; Pc- P. cristiferum)

\section{CONCLUSIONS}

Both lichens were shown to display inhibitory activity against seed mycoflora of ground nut and sorghum. $P$. cristiferum was effective in inhibiting mycoflora to higher extent when compared to $P$. tinctorum. The antifungal activity of lichens observed in this study could be related to the presence of bioactive secondary metabolites in the extracts. Isolation of active principles from these lichens and their inhibitory activity against seed mycoflora are to be carried out.

\section{Conflict of Interest}

None declared.

\section{REFERENCES}

Agbor, A.M. (2015). Methanol extracts of medicinal plants used for oral healthcare in Cameroon. Biochemistry and Pharmacology 4: 164.

Al-Aksar, A.A.A. (2012). In vitro antifungal activity of three Saudi plant extracts against some phytopathogenic fungi. Journal of Plant Protection 52(4): 458-462.
Al-Reza, S.M., Rahman, A., Ahmed, Y., Kang, S.C. (2010). Inhibition of plant pathogens in vitro and in vivo with essential oil and organic extracts of Cestrum nocturnum L. Pesticide Biochemistry and Physiology 96: 86-92.

Awasthi DD. A compendium of the macrolichens from India, Nepal and Sri Lanka. Bishen Singh Mahendra Pal Singh, Dehra Dun, 2007.

Babiah, P.S., Upreti, D.K., John, S.A. (2014). An in vitro analysis of antifungal potential of lichen species Parmotrema reticulatum against phytopathogenic fungi. International Journal of Current Microbiology and Applied Sciences 3(12): 511-518.

Bahraminejad, S., Amiri, R., Ghasemi, S., Fathi, N. (2013). Inhibitory effect of some Iranian plant species against three plant pathogenic fungi. International Journal of Agriculture and Crop Sciences 5(9): 1002-1008.

Candan, M., Yılmaz, M., Tay, T., Erdem, M., Türk, A.Ö. (2007). Antimicrobial activity of extracts of the lichen Parmelia sulcata and its Salazinic acid constituent. Zeitschrift für Naturforschung 62c: 619-621. 


\section{Prashith Kekuda et al.,}

Chandra, M., Mahesh, N.M. (2013). Antifungal activity of medicinal plant extracts against seed-borne pathogenic fungi. Acta Biologica Indica 2(2): 481-483.

Chang, H., Cheng, Y., Wu, C., Chang, S., Chang, T., Su, Y. (2008). Antifungal activity of essential oil and its constituents from Calocedrus macrolepis var. formosana Florin leaf against plant pathogenic fungi. Bioresource Technology 99: 6266-6270.

Devi, A.B., Mohabe, S., Reddy, M., Nayaka, S. (2015). Efficacy of a potential lichen Parmotrema andinum (Müll. Arg.) Hale against pathogenic microorganisms. Journal on New Biological Reports 4(2): 149-156.

Divakar, P.K., Upreti, D.K. Parmelioid lichens in India. Bishen Singh Mahendra Pal Singh, Dehra Dun, 2005.

Goel, M., Dureja, P., Rani, A., Uniyal, P.L., Laatsch, H. (2011). Isolation, characterization and antifungal activity of major constituents of the Himalayan lichen Parmelia reticulata Tayl. Journal of Agricultural and Food Chemistry 59: 2299-2307.

Halama, P., Van Haluvin, C. (2004). Antifungal activity of lichen extracts and lichenic acids. BioControl 49(1): 95107.

Jayalal, U., Divakar, P.K., Joshi, S., Oh, S., Koh, Y., Hur, J. (2013). The lichen genus Parmotrema in South Korea Mycobiology 41(1): 25-36.

Karabulut, G., Ozturk, S. (2015). Antifungal activity of Evernia prunastri, Parmelia sulcata, Pseudevernia furfuracea var. furfuracea. Pakistan Journal of Botany 47(4): 1575-1579.

Karunaratne, V., Bombuwela, K., kathirgamanathar, S., Thadhani, V.M. (2005). Lichens: A chemically important biota. Journal of National Science Foundation Sri Lanka 33(3): 169-186.

Kekuda, P.T.R., Ramesh, D., Ramesh, D., Mesta, S.C., Onkarappa, R., Vinayaka, K.S. (2015). Radica scavenging, antmicrobial and insecticidal efficacy of Parmotrema cristiferum and Dirinaria applanata. Science, Technology and Arts Research Journal 4(1): 95-102.

Kekuda, P.T.R., Vivek, M.N., Kambar, Y., Manasa, M. (2014). Biocontrol potential of Parmotrema species against Colletotrichum capsici isolated from anthracnose of chilli. Journal of Biological and Scientific Opinion 2(2): 166-169.

Kowalski, M., Hausner, G., Piercey-Normore, M.D. (2011). Bioactivity of secondary metabolites and thallus extracts from lichen fungi. Mycoscience 52(6): 413-418.
Sci. Technol. Arts Res. J., Jan-March 2016, 5(1): 80-83

Michlig, A., Ferraro, L.I., Elix, J.A. (2014). A new species of the lichen genus Parmotrema from Argentina (Parmeliaceae, Ascomycota). Phytotaxa 191(1): 172-176.

Molnár, K., Farkas, E. (2010). Current results on biological activities of lichen secondary metabolites: A review. Zeitschrift für Naturforschung 65c: 157-173.

Nanayakkara C, Bombuwela K, Kathirgamanathar S, Adikaram NKB, Wijesundara DSA, Hariharan GN, Wolseley P, Karunaratne V. (2005). Effect of some lichen extracts from Sri Lanka on larvae of Aedes aegypti and the fungus Cladosporium cladosporioides. Journal of National Science Foundation Sri Lanka 33(2): 147-149.

Orange, A., James, P., White F.J. Micro-chemical methods for the Identification of lichens. London. British Lichenology Society, 2001.

Punja, Z.K., Utkhede, R.S. (2003). Using fungi and yeasts to manage vegetable crop diseases. Trends in Biotechnology 21(9): 400-407.

Shivanna, R., Garampalli, R.H. (2015). Evaluation of fungistatic potential of lichen extracts against Fusarium solani (Mart.) Sacc. causing Rhizome rot disease in Ginger. Journal of Applied Pharmaceutical Science 5(10): 67-72.

Shrestha, G., St. Clair, L.L. (2013). Lichens: a promising source of antibiotic and anticancer drugs. Phytochemistry Reviews 12(1): 229-224.

Suberu, H. (2004). Preliminary studies of inhibitions in Aspergillus flavus with extracts of two lichens and BentexT fungicide. African Journal of Biotechnology 3(9): 468472.

Thadhani, V.M., Choudhary, I.M., Khan, S., Karunaratne, V. (2012). Antimicrobial and toxicological activities of some depsides and depsidones. Journal of National Science Foundation Sri Lanka 40(1): 43-48.

Tiwari, P., Rai, H., Upreti, D.K., Trivedi, S., Shukla, P. (2011). Antifungal activity of a common Himalayan foliose lichen Parmotrema tinctorum (Despr. ex Nyl.) Hale. Nature and Science 9(9): 167-171.

Vivek, M.N., Manasa, M., Kambar, Y., Kekuda, P.T.R., Raghavendra, H.L. (2014). Antifungal efficacy of three bioactive Parmotrema species from Western Ghats of Karnataka, India. International Journal of Agriculture and Crop Sciences 7(12): 968-973. 